\title{
Technoscientific reports, nuclearity and uranium production in Caetité/BA as a public issue
}

\author{
Israel de Jesus Rocha
}

${ }^{1}$ Universidade Federal do Amazonas, Manaus, Amazonas, Brasil.

\begin{abstract}
Uranium mining in Brazil has raised numerous questions from diverse actors in civil society, social movements and public authorities. This article aims to describe how uranium production becomes a public issue based on technoscientific reports produced by institutions and research groups interested in presenting a diagnosis of the situation surrounding the mine in Caetité, Bahia, Brazil. After outlining the reports, we describe the emergence of a demand for monitoring and greater transparency as a way of regulating uranium production in the region, especially linked to the health of residents and workers and the contamination of the environment and water bodies. The role of scientists expands the articulation of strategies developed by local and nonlocal social movements concerned with nuclear problems to make the consequences of nuclear energy and its production chain a public issue.
\end{abstract}

Keywords: Uranium; Nuclear; Technoscientific reports; Nuclearity.

São Paulo. Vol. 24, 2021

Featured Topics: Decolonial Insurgences and Emancipatory Horizons: Contributions of Political Ecology

DOI: http://dx.doi.org/10.1590/1809-4422asoc20200093r2vu2021L4TD 


\section{Introduction}

Uranium mining for nuclear fuel production is carried out in Brazil by Indústrias Nucleares do Brasil ${ }^{1}$ (INB) near the rural town of Caetité, southeast Bahia. It has raised a series of questions in relation to monitoring the health of workers and residents of the neighboring communities, as well as regarding the contamination of the region's environment. The INB is responsible for the extraction of uranium in the only uranium mine in operation in Brazil. Since the beginning of its operations in the region, at the end of the 1990s, the company has been convicted numerous times in the courts due to contamination of rivers and the soil, stemming from uranium production (PAES, 2019). The accidents were registered by the company at different times and in different situations (BORGES, 2015i, VILASBOAS, 2012, 2012b, 2014, 2015) and presented in research reports realized by independent laboratories (CHAREYRON, 2014; 2019), which were then made public through the intervention of local and non-local social movements.

During this period, a network of researchers at universities and research groups and centers, developed independent data collection methodologies for the information presented by the INB, so as to analyze the interferences and impacts generated by uranium extraction and processing in the Caetité region (CUNHA et al., 2013; PORTO et al., 2014; FINAMORE, 2015; CHAREYRON, 2014, 2019; RÊGO et al, 2019). Data about the health of residents and workers and the environmental situation were systematically collected and analyzed by researchers to obtain a more detailed picture of the consequences of uranium mining in the region. The findings are in line with other studies (PORTO, 2014, FINAMORE, 2015, ZHOURI, 2018) that repeatedly uncover a context of environmental injustice when considering the mining industry and the construction and operation of large-scale enterprises. In addition to the institutions and research groups, social and environmental movements involved in the nuclear question have increased awareness of the problematic situations (DEWEY, 2012; MARRES, 2012) stemming from uranium production and nuclear energy in Caetité. The publicization of the technoscientific reports that show the dynamics and consequences of uranium extraction is spearheaded by a network of actors made up of non-specialists interested in bringing the problems resulting from the mine's operation into the public sphere.

The independent work developed by the researchers and members of the social movements began to mobilize actors in the public arena capable of producing consistent information about uranium production. These data were initially collected and organized in the report The Cycle of The Nuclear, by Greenpeace, in 2008 and 2012 with the involvement of laboratories active at the international level such as that of the Commission de Recherche et D'Information Independantes sur la Radioactivité (CRIIRAD) (CHAREYRON, 2014, 2019), which has experience in monitoring regions with nuclear infrastructure. In addition to the monitoring efforts focused on measuring the levels of environmental radiation, other actors have sought to develop studies into the impact on the health of residents neighboring the mine, as well as its workers (PORTO et al., 2014; FINAMORE, 2015; RÊGO et al., 2019).

1 - Brazilian Nuclear Industries 
With the aim of understanding uranium production as a public question, we need to consider, following Gusfield (1981), that a problem can be understood to be public when it begins to require attention from and mobilize collective action for its resolution. According to Gusfield (1981), there is an important difference between a social problem and a properly public one, given that the first does not necessarily require mobilization for its resolution. Public problems go beyond the local sphere, and are informed by controversies and involve publicly recognized instances capable of intervention.

According to Dewey (2012), publics are constituted when problematic situations place people who feel themselves to be affected within a context that demands an investigation of causes and effects, an identification of those responsible and the possibility for change. Directly or indirectly affected publics begin to develop processes of publicization with the aim of making the question a concern for the wider public.

Based on this scenario, the present article proposes a discussion about uranium extraction as part of a broader process, involving politics, technology and conceptions surrounding the nuclear, which Gabrielle Hecht (2012) called 'nuclearities'. We start from the work of the scientific actors and their production of evidence regarding the consequences of uranium mining in Caetité. We seek to describe the strategies applied to produce counter-expertise and the controversies surrounding the evidence developed as a way of publicizing the problems surrounding uranium and its transportation, and the nuclear in general (BARTHE, 2006; BAISNÉE, 2001) as questions of environmental injustice.

To describe the mobilization of problems related to uranium and the nuclear as a public question, we start from two technical reports produced by institutions and research groups. We seek to understand the situation surrounding uranium production in the Caetité region, taking these reports as an effective summary of the situation around uranium production in the region. The reports were collected between 2013 and 2019 and are part of a data set from research that aims to study uranium production and the nuclear as public questions capable of mobilizing a wide range of actors such as social movements, activists, scientists and local and non-local networks involved in the nuclear question. The way in which the scientists produce what Callon (2995) called 'punctuations' of a heterogenous network, as points through which human and non-human actors circulate, generates the visibility of a wider and more precarious network.

The reports used in the analysis of uranium production and of the nuclear as a public question, were those produced by the team of the Centro de Saúde do trabalhador e Ecologia Humana da Fiocruz ${ }^{2}$ (CUNHA, 2013), and that from the team of Marcelo Porto (2014), also a researcher of the Fiocruz. Using these reports, it was possible to carry out a description of the actors who made up the publics (DEWEY, 2012), concerned with the question of the nuclear in Caetité. 


\section{The technoscientific reports about uranium in Caetité}

In observing the cases that involve uranium, we note points of controversy that mobilize heterogeneous actors and open up a horizon of effectuation (FREIRE, 2010, 2013) for processes of publicizing the nuclear (BARTHE, 2006; BAISNÉE, 2001). The problem of the extended exposure to radioactive material complicates issues related to the nuclear. On one hand, it requires long term studies, and on the other, an analysis of the diverse variables that make the realization of studies into the impact of uranium on the day-to-day lives of publics affected by nuclear infrastructure more complex.

An impact study was produced by the team of the researcher Arnaldo Levy Lassance Cunha, associated with the Centro de Saúde do trabalhador e Ecologia Humana da Fiocruz (CESTEH/FIOCRUZ). In 2008, the INB signed a contract with A Fundação para o Desenvolvimento Científico e Tecnológico em Saúde 3 (FIOTEC) to carry out a descriptive analysis of the illnesses indicated by the specialized literature as potentially related to exposure to ionizing radiation. The study used the Sistema de Informação sobre Mortalidade ${ }^{4}$, of the Ministry of Health, adopting the number of deaths by municipality of residence, grouped according to cause of death as the unit of analysis and problematization. The researchers also took sex, age, year of death and geographic region into account (CUNHA et al., 2013).

Published in 2013, the report sought to present an overview of the health of the region in relation to the presence of the mine. The circulation of the report produced an effect in the media and was highlighted by Vilasboas (2014, [SP]),

In 2008, it [the INB] contracted another group of researchers from the Fiocruz (FIOTEC/Fiocruz), to fulfill the IBAMA's environmental licensing conditions. These conditions required monitoring the health of the workers and of the population surrounding the mine. Using data from this research, they sought to hide the harmful effects of uranium production and widely publicized in the media that "Fiocruz shows: uranium doesn't provoke an increase in cancer cases". It is important to highlight that the final report from this research had already indicated an increase in cancer in the area of the mine. But the INB never made this information public. The fact is that, when pressured by civil society organizations, in 2013, the president of the Fiocruz created a working group which evaluated and classified this research as being merely "exploratory and inconclusive".

In the information released by the INB at the time, we can observe how the company presented a narrative that emphasized an absence of a relation between their activities and the possibility of an increase in diseases associated with exposure to radioactive elements. However, when the information that there was no relationship between the mine and an increase in cancer cases was made public, only five years of operation of

3- The Foundation for Scientific and Technological Development in Health.

4 - Mortality Information System. 
the Unidade de Concentração de Urânio 5 (URA) - Caetité had passed, which would not have been a sufficient period to arrive at any conclusive finding. Although the study itself was inconclusive, the INB used the data to affirm that there was no direct relationship between the uranium production and deaths from cancer (FIRPO, 2014).

\begin{abstract}
A Fundação para o Desenvolvimento Científico e Tecnológico em Saúde researched the causes of deaths from cancer that occurred in the State of Bahia, and compared these with what was observed in our region between 1995 (prior to the start of the activities of the URA Caetité) and 2005. The finding that they arrived at is that there is no difference between the number of cases recorded here in comparison with the cases registered in the whole of Bahia.
\end{abstract}

These are some of the initial results of the research that is being undertaken under recommendation by the IBAMA. This allows both the residents, the local authorities and the INB, and the national and international organizations that monitor the URA to have reliable, scientifically grounded information, regarding the health of people living in the region (MOURA, 2009) 6 .

In another epidemiological study, Porto et al. (2014) showed that the uncertainty surrounding the ideal period starting from the opening of the mine, and necessary to determine if there was an increase or reduction in cancer cases is a relevant data point. Different to the study carried out by Cunha (2013), the methodology adopted by Marcelo Firpo, actively tracked cases and made a subsequent comparison with the information found in public health system data base used by the Sistema Único de Saúde ${ }^{7}$.

The research, which aims to systematize information regarding neoplasm cases observed by local community organizations, is coordinated by the titular researcher of the Fiocruz (RJ), Marcelo Firpo, and has confirmed 21 cases of the disease (17 deaths and 4 in treatment). According to Firpo, an active search for possible neoplasm cases by community organizations is a basis for complementary and important information given the gaps in the official data bases. "Despite the statistical limits found in the analysis of the incidence of health problems in communities with tens or hundreds of families, the occurrence of cases of rare neoplasms in areas potentially exposed to radiation, should be investigated by the healthcare system, environmental agencies and by the polluting entities" (VILASBOAS, 2014).

In addition to presenting the methodology adopted in the study by Firpo's team, Vilasboas also outlines the development of networked study undertaken by local social

\footnotetext{
5 - Uranium Concentration Unit.

6 - The text was produced by the media relations of the INB and released in local newspapers.

7 -Universal Healthcare System.
} 
movements to obtain information through methodologies considered not only scientific but also participatory and inclusive. The local actors began developing the research in a systematic manner with the aim of allowing the use of tools for monitoring cases and situations of contamination, which would not have been possible without the mediation of devices capable of reading and producing data about the contaminated areas. This was done in partnership with institutions such as FIOCRUZ and CRIIRAD.

The confirmed cases were georeferenced with the aim of locating them in possible risk areas. 8 cases of leukemia and 3 [cases of cancer] in the digestive tract stood out. It was also notable that half the cases of leukemia (4) were in the age range of 1 to 17 . The communities where these individuals reside (or resided) are in Caetité (Juazeiro, Pau Ferro, Maniacu, Malhada, Gameleira, Cachoeirinha, Fazenda Araçá, Riacho da Vaca) and Lagoa Real (Espigão, Barbeiro, Salinas, Rio Abaixo). The research began in 2011, in an initiative by the "Environmental Health and Risk Evaluation" Working Group from the EJOLT Project (Organizações de Justiça Ambiental, Passivos e Comércio), an international league of scientists, organizations and activist groups that study and give support to environmental justice movements, such as those that question nuclear activities, in numerous countries. (VILASBOAS, 2014).

The role of non-local working groups met a demand from local organizations, in evidence since the start of the mine's operation, to apply pressure on the outreach strategies adopted by the INB regarding the problems of the nuclear in the region. Of the studies that consider different data collection and analysis strategies, the doctoral thesis defended by Renan Finamore in 2015 is part of a systematization of the publicization of the nuclear, producing and presenting technical data developed in partnership with laboratories and research institutes. Finamore's thesis (2015) seeks to present cases of death from cancer in the region, compiled in collaboration with families monitored by the Diocese of Caetité.

The starting point for the development of this research, in terms of locally systematized information, was the survey of cases of death from cancer in the region, carried out by Father Osvaldino Barbosa, while he was active in the parish of the Diocese of Caetité. The cases were collected from the families who frequented the parish, with the intention of gathering evidence to counteract the official discourse of the INB of denying the risks to the health of the population, due to the mine's activities. Until 2011, Father Osvaldino had discovered a total of 50 cases, that were listed in a table which included the following fields: place (community of origin); age; death (date of death); cause of death; and cemetery (place of burial). (FINAMORE, 2015, p.142)

One of the issues that Finamore (2015) presents in his study suggests that the 
processes of publicization are still under construction, with diverse problems for their effectuation as voices that could be heard in the public sphere, capable of defining limits for the problems of the nuclear. While there was an advance in terms of mobilizing multiple, local and non-local actors concerned with questions related to the nuclear, implying an effort on the part of diverse researchers, Finamore also shows the importance of the local voices of those directly affected that can enter into dialogue with the regulatory instances overseeing the sector.

\section{Controversies regarding epidemiological studies}

One of the requirements involved in the installation and operation of the URACaetite was the elaboration of an epidemiological study into the impact of mining on the health of those who lived in the municipalities neighboring the mine. This study was commissioned to meet the conditions of the operating license 274/2002 conceded by the IBAMA, which solicited an,

Epidemiological study of the morbi-mortality related to the eventual occurrence of pathologies related to genetic damage and malign neoplasms in the area of influence of the Unidade de Concentrado de Urânio (URA), of the Indústrias Nucleares do Brasil (INB) - Caetité in the State of Bahia. (CUNHA et al. 2013. p.01).

The study makes clear that a descriptive analysis of the diseases indicated by the specialized literature as related to exposure to ionizing radiation, which are typical of uranium mining regions according to the report, had to be undertaken. The study considered a 15-year period between 1995 and 2010, taking as its reference the five years prior to the start of operations and the 10 years following this date.

The findings used by the researchers in this study show a relationship between an improvement in identification methods, allowing a more accurate determination of what previously appeared as poorly defined causes, and a consequent increase in cancer cases, given the apparent improvement of the system over the years. Even if an increase in the number of neoplasm cases was observed, (associated with the influence of radioactivity) the study does not identify the operation of the mine as a causal factor for the increased cancer cases.

The poorly defined cases show a tendency to decrease, falling to $20 \%$ in 2010, while the neoplasms show a tendency to increase, reaching around 20\% in 2010. Both show an atypical oscillation in 2009. With the improvement in health diagnostics and in the registering of the causes of death, a reduction in the number of deaths from poorly defined causes and a subsequent increase in the number of cases amongst groups with defined causes, including neoplasms, is expected. This increase, in fact, is artificial, since it indicates only a transfer of the deaths previously counted as "poorly defined" to groups with a 


\section{defined cause of death. (CUNHA et al. 2013. p.07)}

Based on a comparison of the data within the previously mentioned timeframe, the CESTEH/Fiocruz study did not present a conclusion regarding the cases. However, it offered some clues for us to understand how the INB constructed the narrative based on the researchers' findings. We can see below how the study presented its conclusions.

The health of the population of the municipalities in the area of influence of the Unidade de Concentrado de Urânio presents results that varied over time, when compared with the values obtained for the State of Bahia and for the chosen municipalities and regions of reference. In 2008, workshops with managers of the Municipal Secretaries of Health, meetings with the communities of the two municipalities, and awareness raising campaigns in partnership with the doctors of the Fundação Hospitalar Senhora Santana de Caetité and the Regional Council of Medicine of Bahia, were realized, to improve the completion procedures for the death records. A training course for technicians in the area of health supervision, for the notification and investigation of local deaths was also realized. The data presented in this report show an improvement in the reporting of cause of death, leading to a reduction in the number of deaths attributed to poorly defined causes and an increase in the number of cases attributed to groups with defined causes, including neoplasms, following the awareness raising campaign with workers in the healthcare area. The comparison between the areas of influence and reference showed a difference in the distribution of deaths from malignant neoplasms, with higher rates of mortality in the areas of influence in comparison with the reference area, in 2009 and 2010. However, it is necessary to consider that the elevated frequency of poorly defined causes for deaths in the recorded data made any conclusion regarding the ultimate relationship between naturally occurring radiation and deaths from neoplasms in the study region, inconclusive. (CUNHA, A. 2013.p.10)

The issue that will intensify the controversy between this study initiated in 2008 and the preliminary report carried out by the other team from the Fiocruz, lies in how the INB publicized the problems related to the nuclear. This involved an effacement of the possible association between the mining activities and cancer cases. This was highlighted by local and non-local groups who presented another reading of the report, pointing out how the company made use of the findings without necessary discussions regarding its consequences, thereby magnifying the presence of disinformation. We can observe that the study highlights a concern with the improvement in the registration of deaths and an intention to implement a more specialized supervision system in the region, a point that is also of interest for groups critical of the mine.

In the preliminary report elaborated by Porto et al. (2014), a question which stands out concerns the health of workers and residents who live in the mine's area of influence. 
In this regard, an affirmation by Zoraíde Vilasboas about the use of scientific information by the INB to divert attention away from research looking into the health of the residents is notable. For Vilasboas, there was

Inappropriate use of the scientific research by the INB to reject the possibility of harm to the health of the population, manipulating existing scientific uncertainties to deny the existence of a causal nexus between uranium mining activities and the occurrence of health problems, contributing to the dissemination of disinformation (VIALSBOAS apud PORTO, 2014, p. 24).

The preliminary report (PORTO, 2014) not only indicates problems stemming from the inadequate use of research on the part of the INB. It also criticizes the way in which the report was organized, leading to problems such as an appropriation of the data by the company to magnify the seeming lack of a causal relationship between mining and the cancer cases.

Amongst other limitations, the research did not seek to investigate the possible relationship between the establishment of mining and health outcomes, having adopted an ecological focus as its methodology. Further, the poor quality of the death records for the region hampered analysis. It is also worth noting that: (1) the study evaluates mortality rates for cancer and not incidence (occurrence of new cases); (2) there is no segmented analysis for cancer types that have a clearer relationship with exposure to ionizing radiation; (3) the latency period (the interval between exposure and the occurrence of health problems) is not considered. Despite being inconclusive, the last report of this research found that, from 1995 to 2010, there was a statistically significant difference between the distribution of deaths from neoplasms, with the presence of higher rates in the area of influence, in comparison with the reference areas. This is also reflected in the improvement in the quality of the death records for Brazil and Bahia more specifically. (PORTO, et al. 2014, p. 24)

Critics emphasize an alternative method that we will refer to here as counterexpertise, which is the proposition of a project of community epidemiology. The counterexpertise scenario which started from the 2008 Greenpeace report becomes broader and more heterogeneous as multiple actors begin to be affected by problems of the nuclear. The publicization of questions posed by uranium production cannot overlook the fact that the mineral is part of an extensive chain of energy production.

The accidents that characterize this type of energy also lead to a series of criticisms of its production, both in its civil and military applications. These criticisms generate elements able to publicize the diverse problems of the nuclear, implicating the actors who control and regulate the sector in these problems. In the Brazilian case, the INB 
and the Comissão Nacional de Energia Nuclear ${ }^{8}$ (CNEN), come into conflict with actors able to mobilize narratives and practices that call into question the naturalized narrative propagated by the sector and based on economic growth regarding uranium production.

The political and judicial disputes come into contact with questions of a scientific and methodological order that consider the ways of collecting and monitoring information related to the problems of the nuclear. As Gabrielle Hecht argues (2012, p. 21), the concept of nuclearity is an ambiguous, polyvalent term, with political, social, judicial, techno-scientific and bodily dimensions that involve the production of the nuclear in spatiotemporally different contexts.

Nuclearity is not an essential property of things nor a property distributed between things. Radiation matters, but its presence alone is not sufficient to make the mines a nuclearized work place. For mines to be recognized as nuclear sites from the scientific, political or cultural standpoint, the level of radiation needs to be detected and registered by laboratory instruments and comparative data. If the instruments or institutions are absent, or if they fail, or if the connections between them are weak, then the mines are treated in the day-to-day context as places connected with dangerous work and not recognized as specifically nuclearized sites. (HECHT, 2016, p. 21).

In a broader sense, to be able to consider the Caetité mine as a place of nuclearities, it is necessary for the work of counter-expertise to emphasize the problems associated with the process of uranium extraction for nuclear fuel production. To this end, it is also important to investigate the processes by which uranium becomes a significant non-human actor, situated within the logic of problems of the nuclear, being mobilized (extracted) from the soil and circulated in heterogeneous chains that involve the politics of the nuclear in Brazil in connection with aspects of national interest. These processes imply a series of elements that involve devices used to measure radiation and at the same time, storage strategies for waste products produced by the mines and nuclear powerplants.

Radioactivity is a physical phenomenon that exists independently of whether it is detected or politicized. Nuclearity on the other hand, is a technopolitical phenomenon resulting from the political and cultural configurations that affect the scientific and technical phenomena. It emerges from the social relations according to which knowledge is produced. Nuclearity is not the same everywhere: it differs in the United States and France, in Namibia or Madagascar, or in South Africa or Gabon. Nuclearity is not the same for everyone: its meaning is not the same for geologists or physicists, for geneticists or epidemiologists, or employers or workers; or for Nigerians or Canadians. Nuclearity does not stay the same over time: between the 1940s and 1990s, its materialization and its distribution changed dramatically. (HECHT, 2016, p.22)

8 - National Nuclear Energy Commission. 
In this sense, nuclearity intensifies the way we analyze the problems of the nuclear because it allows us to observe how publics are constituted. In following these actors, especially through the reports, we perceive the strategies of amplification for the problems of the nuclear. This reveals the continuities between narratives of local experiences associated with cancer cases and environmental problems connected with uranium extraction, as well as their connections with Brazil's nuclear production more broadly. For Porto et al. (2014), these processes need to be carefully monitored and accompanied by public institutions.

It is worth noting that uranium mining should be considered of high risk to worker health and surrounding populations, requiring careful monitoring by public oversight and regulatory bodies, in an independent and technically qualified manner. Therefore, we consider the realization of new studies, that extend the investigation of the possible impacts of uranium mining and processing on the region, fundamental. Additionally, a local Public Health service that would allow for the monitoring of the health of the population and the workers potentially exposed should also be established. This would generate and exchange information with the population in an ongoing and transparent manner, effectively dealing with local concerns related to health. (PORTO et al. p.25)

A criticism of the first study, highlighted by the researchers, was that its scope was limited to identifying cases based on deaths, thereby ignoring cases in people who were still alive, or cases of people who moved to other cities such as São Paulo, Rio de Janeiro and the state capital Salvador, for treatment. An active search for cases, would more accurately identify the largest number of cases associated with the mine's operation. This is also important given that the previous study also failed to undertake a detailed characterization of cancer types, which would further affect the data's accuracy.

For Porto et al. (2014), using an active search methodology for cancer cases can increase the availability of precise information regarding cases and expand the possibility for action by publics engaged in demanding greater proactivity from the State to resolve problems related to uranium production in the region.

As a primary goal, the research seeks to systematize information regarding neoplasm cases obtained by local community organizations, analyzing them in comparison with official data for morbidity and mortality existent in the DATASUS data base. Amongst the secondary aims of the research, we can highlight: - Georeferencing information obtained from local community organizations regarding cancer cases, seeking to verify proximity to possible sources of exposure in the area of influence of the uranium mine; - Train and strengthen local organizations and communities through workshops regarding the effects on health from exposure to ionizing radiation, especially in 
the context of exposure at natural levels in areas of influence of the uranium mine, including the presentation of a final technical report with the result of the present study; - Develop a technical report to be sent to the SUS, at the federal level (Department of Environmental and Worker's Health), and to state and municipal levels in the area of influence (Caetité and Lagoa Real), as well as to the INCA (National Cancer Institute) and research groups that act in the region. In methodological terms, two main hypotheses guide the project. The first concerns the importance of the local and situated knowledge of the community organizations regarding health and environmental problems as a knowledge production strategy. (PORTO et al. p.26)

An important part of the methodology is the connection between the work of the scientists associated with the project and the work of local groups and community organizations in the active production of information about cancer cases.

In common with diverse initiatives of collective mobilization seeking to produce knowledge, the case in question is characterized by a feeling of injustice when confronting the negligence and inertia of institutions, companies, scientists and professionals in light of the suspicions or complaints presented. The other aspect is the possibility of such populations assuming their role as subjects of the very reality that they experience, which includes the disputes for the validation of arguments that explain and contextualize the problems and controversies in question. (PORTO et al. p.27)

The difficulties in the application of the methodology highlighted by Finamore, highlight the way the INB also acts to promote versions of the nuclear that come into conflict with those put forth by local groups and non-local organizations interested in the problems of the nuclear. This form of intervention also indicates an intention on the part of the company, which seeks tools to maintain its influence on residents, using discourses that naturalize or minimize the evidence produced based on the production of counter-expertise.

Even with the criticisms from the report produced by Cunha's team (2013), the release of the epidemiological data from the community shows the limits of the public's participation in questions of the nuclear, especially regarding aspects related to health. Additionally, this also indicated an extension of the groups that act to promote information focused on the description of cases in a broader manner. This study also mobilized the INB. If the INB believed that the narrative of natural exposure to uranium could be publicized to legitimize the work of extraction, following the forms of counter-expertise produced by local and non-local groups, the company needed to use alternative strategies to sustain the version that kept interest in mining alive. 


\section{Uranium and the publicization of its problems}

Uranium production in Caetité is part of wider, more complex processes, that involve global forms of the nuclear and the place of Brazil in the nuclear world in a physical, political and technological way. Exposure to uranium and its byproducts is not immediately accessible to the senses. The need for measurement using technical devices makes the role of science essential, as a mediator of the processes of publicization of the nuclear. As Mendes and Araújo $(2010 ; 2011)$ affirm, science retains techniques and instruments necessary to confer existence on and to establish what Hecht $(2012 ; 2016)$ called the "nuclearity of uranium". As Hecht insists, the nuclear is the technical and political result of historical processes in which policies shape technologies, just as the inverse is also the case.

Policies shape their technologies, but technology also shapes policy. Materiality is of fundamental importance. Many atomic explosions really can destroy the planet; exposure to radiation really can cause cancer. However, as numerous studies regarding science and technology show us, material realities emerge from complex networks in which the social and the technical are inseparably intertwined. In relation to exposure in the workplace, for example, the instruments, labor relations, scientific disciplines, and specialized controversies and lay knowledge combine to create what Michielle Murphy calls the "regimes of perceptibility" - a set of social and technical elements that make certain risks and effects on health visible and others invisible (HECHT, 2009, p.899)

The processes of publicization of the nuclear make questions related to the environment and to the bodies of residents and workers, matter. It is through the mediation of technoscientific objects that the consequences of uranium production become visible for publics concerned with the problems of the nuclear. Epidemiological studies stimulate the emergence of bodies as sites manifesting traces of the construction of nuclearity in Caetité. Environmental monitoring studies make clear the complex processes that involve the region in the dynamics of a becoming nuclear. The beings of the nuclear (HECHT, 2012) configure themselves starting from the marks of extraction on the landscape up to the devices that mediate the materiality of radiation and its consequences understood as problematic.

In addition to the devices that materialize scientific monitoring techniques and practices, in the case of Caetité, we can observe the interconnections between the local forms of apprehending phenomena related to the nuclear, and the identification of variations in the local landscape. The impacts on rural production, on the identification of supposedly contaminated regions, and the strategies of data collection and modeling also become relevant. Both the CRIIRAD, with the monitoring data obtained from technoscientific devices, and the FIOCRUZ, with its attempt at crossing information regarding cancer cases from the community epidemiology based on participatory methodologies, shape nuclearities and publicization processes in relation to the problems of the nuclear. 
The problematic situations related to the nuclear in which the actors find themselves immersed, mobilize numerous forms of engagement with the problems to be resolved, leading to diverse starting points to produce forms of resolution for these problems. Therefore, we can think about the alliances and connections between science and the knowledge of populations and local groups as an attempt to make questions about the nuclear matter for groups beyond those communities directly affected.

The public, in Dewey's sense (2012), is configured and reconfigured starting from the ways in which the actors are concerned with the problems of the nuclear. As such, they produce technoscientific reports about the situation of uranium production that reveal the problematic dimensions of the nuclear based on still little explored points. At the same time, they constitute themselves as actors interested in the nuclear beyond its scientific dimensions, revealing political and material aspects, based on methodological processes different to those adopted by the mining company. The reports reveal procedures that either make cancer cases and deaths visible, or make them difficult to perceive, and mobilize non-local actors and devices that make the actions of the nuclear components derived from the uranium perceivable.

At the same time, the reports open up space for what Gusfield (1981) considers the emergence of public problems. For Gusfield, public problems emerge when conflicts, controversies and debates begin to occupy the public sphere, affecting the actions of public bodies and organizations in terms of the disputed meanings and versions presented by the actors involved with the problem.

In this sense, the studies begin to exercise a role in the construction of the narratives and practices, grounding the senses of the nuclearities, which involve the practices of the actors around the activity of mining, especially in the regions neighboring the mine. Demonstrations begin to make use of information from scientific studies. Claims in the legal field begin to cite excerpts from research developed by experts. Activists begin to demand more time and care for the installation of future plants for mining.

Beyond its manifestations in newspaper articles, manifestos and pamphlets, the processes of publicization of the nuclear begin to reveal a broader form of engagement for those who are involved with the problems of the nuclear in Caetité. The different ways of producing expertise about uranium expand the senses of nuclearity and the experience of injustice, both environmental and in relation to the local populations, acquiring a potential to raise awareness about the effects of mining and of the nuclear on the region.

At the same time, a process of increasing generality is necessary (BOLTANSKI; THÉVENOT, 1999) so that bodies and the environment can achieve a presence significant enough to change the technological and political frame of reference, allowing for the embodiment and situation of nuclearity in the public sphere. It is starting from the processes of desingularization of the problems related to the contaminated groundwater and cancer cases, that the environment and bodies gain force and influence to be able to intervene in the problems resulting from mining in the region.

The processes of publicization that generalize the cases become visible when workers and residents begin to demand permanent monitoring and the resulting data 
gains a wider public attention, highlighting the relations between the mining operation and cases of disease related to the nuclear. This is a movement that begins to attribute a moral and material responsibility to the State, through the agencies related to the sector, and a weakening of the narratives produced by the INB that relate the problems of the nuclear to natural causes.

The practices of those who demanded more transparent monitoring of the operations of the nuclear become more heterogeneous, incorporating diverse forms of producing visibility for questions of the nuclear. This becomes more relevant in so far as these movements highlight the possibility of immense environmental liabilities and the uncontrolled increase of disease related to the nuclear. There is, therefore, a line of action that mixes bodies and the environment which produces claims of legitimacy regarding the problems related to mining. And the technical reports and epidemiological studies produce senses of nuclearity that begin to compose the activisms and media expressions of those involved in processes of publicization of the problems of the nuclear. According to Hecht (2009), to the extent that radiation invades the environment and infiltrates bodies, it opens up political possibilities for its problematization in a public space constituted by a multiplicity of actors.

Prior to the publication of the successive technical reports and preliminary epidemiological studies undertaken by the counter-expertise groups, claims were restricted to petitioning undertaken via regulatory bodies such as the Ibama, the CNEN, and the INGA, amongst others. Beginning with the processes of publicization of the problems of the nuclear through reports and studies, the scope of the demands gained greater form and force. They informed both the May 15 negotiations, when a road block of trucks going towards the INB occurred, and the negotiations for the establishment of a specialized cancer unit in the Caetité region. At the same time that they expand the forms of problematization of issues related to the nuclear, these actions, via the reports, also constitute the publics that aggregate around these questions.

\section{Conclusion}

In accompanying how actors begin to publicize the problems of the nuclear through an engagement with counter-expertise, we begin to notice how processes of publicization expand the involvement of local and non-local actors in questions related to mining in Caetité. At the same time, this involvement begins to demand moral and material positions from the agencies that make up the nuclear production cycle, both for its promotion and oversight. This process is intensified with the emergence of scientific actors in the problems resultant from uranium extraction.

In this article, we sought to show how the production of information based on counter-expertise, multiplies the actors engaged in problems associated with uranium, extending the publicization of questions involving the nuclear and the situation of environmental injustice revealed in this process. It also diversifies the ways we construct senses of nuclearity, through which the negative aspects associated with radiation and its effects become visible. The scientific data that deals with radiation in the environment 
and the epidemiological studies that show the possible causal nexus between the nuclear and bodies begin to constitute new actors, new materialities, and regimes of nuclearity. We can no longer affirm that the publics interested in the problem of the nuclear when the INB began processing the mineral are the same as those through which the problems gained generality and a public dimension, via the work of those involved with questions of the nuclear.

The displacements provoked by the actors through narratives and practices based on the idea of counter-expertise extend the range of action of the movements that demand transparency and monitoring of the problems of the nuclear. Starting from the emergence of the scientific actors and their recording devices, publics have access to new sociotechnical arrangements capable of confronting the narratives produced by the INB and of transforming the problems of the nuclear into questions that mobilize publics beyond those directly involved with the consequences of the nuclear in the rural area of Caetité.

\section{Acknowledgements}

The author acknowledge to the people who allow this work to be carried out, especially in their field research, in which I was able to get to know up close the work of many significant people in publicizing nuclear problems as a public issue.

\section{References}

ANTINUCLEAR, Articulação. Governo não vê clima para abertura de setor nuclear. Disponível em: http://brasilantinuclear.ning.com/profiles/blogs/governo-nao-ve-clima-para-abertura-de-setor-nuclear. Acesso em: out 2015.

BAISNÉE, O. Publiciser le risque nucléaire: la polémique autour de la conduite de rejets en mer de l'usine de La Hague. Politix, v. 14, n. 54, p. 157-181, 2001.

BARTHE, Yannick. Le pouvoir d'indécision: la mise en politique des déchets nucléaires. Paris: Economica, 2006.

BOLTANSKI, L.; THÉVENOT, L. A sociologia da capacidade crítica. European Journal of social theory, v. 3, n. 2, p. 359-377, 1999.

CEFAÏ, D.; TERZI, C. Lexpérience des problèmes publics. Perspectives pragmatistes. Paris: EHESS, 2012.

CUNHA, Arnaldo. et al. Estudo epidemiológico na área de influência da mina de urânio em Caetité, Lagoa Real e Livramento de Nossa Senhora no Estado da Bahia. Rio de Janeiro: Fiocruz, 2013. 
DEWEY, J. The Public and Its Problems: An Essay in Political Inquiry. University Park, Pa.: Penn State University Press, 2012.

FREIRE, J. Agir no regime de desumanização: Esboço de um modelo para análise da sociabilidade urbana na cidade do Rio de Janeiro. Dilemas - Revista de Estudos de Conflito e Controle Social, v. 3, n. 10, p. 119-142, 2010.

FREIRE, J. Uma caixa de ferramentas para a compreensão de públicos possíveis: um arranjo de sociologias pragmatistas. Revista Brasileira de Sociologia das emoções, v. 12, n. 36, p. 720-736, 2013.

GUSFIELD, J. R. the culture of public problems: drinking-driving and the symbolic order. Chicago: Chicago press, 1981.

HECHT, G. Africa and the Nuclear World: Labor, Occupational Health, and the Transnational Production of Uranium. Comparative Studies in Society and History, v. 51, n. 4, p. 896-926, out. 2009.

HECHT, G. Being Nuclear: Africans and the Global Uranium Trade. [s.1.] The MIT Press, 2012.

HECHT, G. Uranium africain, une histoire globale. [s.1.] Seuil, 2016.

INGÁ. Nota técnica n. 05/10. Avaliação dos teores de radiação na região de Caetité, Lagoa Real e Livramento de Nossa Senhora. 06 de abril de 2010.

INGÁ. Nota técnica n. 10/10. Liberação do uso das águas dos poços interditados por suspeita de níveis elevados de radiação na região de Caetité, Lagoa Real e Livramento de Nossa Senhora. 14 de abril de 2010 .

LANÇA, I. B. A construção dos problemas públicos: elementos para uma análise do caso Timor. Antropológicas, v. 0, n. 4, p. 113-130, 2000.

MARRES, Noortje. Material Participation: technology, the environment and everyday publics. 2ed. New York, NY: Palgrave Macmillan, 2012.

MENDES, J. M.; ARAÚJO, P. Nuclearidade, trabalho dos corpos e justiça: requalificação ambiental das minas da Urgeiriça e os protestos locais. Sociologia, Problemas e Práticas, n. 64, p. 81-105, dez. 2010.

MENDES, J. M.; ARAÚJO, P. Territórios contaminados, corpos contaminados: Estado, nuclearidade e cidadania em Portugal e França. Configurações. Revista de sociologia, n. 8, p. 33-56, 5 fev. 2011.

PORTO, M. F. DE S.; FINAMORE, R.; FERREIRA, H. Injustiças da sustentabilidade: conflitos ambientais relacionados à produção de energia "limpa" no Brasil. Revista Crítica de Ciências Sociais, n. 100, p. 37-64, maio 2013. 
PORTO, Marcelo; FINAMORE, Renan; CHAREYRON, Bruno. Justiça ambiental e mineração de urânio em Caetité/BA: avaliação crítica da gestão ambiental e dos impactos à saúde da população. Rio de Janeiro: Fiocruz, 2014.

VILASBOAS, Zoraíde. O silêncio, nada inocente, do Programa Nuclear Brasileiro. Ecodebate. 2012. Disponível em: https:/www.ecodebate.com.br/2012/11/09/o-silencio-nada-inocente-do-programa-nuclear-brasileiro-por-zoraide-vilasboas/ acesso em: nov. 2015

. Urânio da Bahia: Caetité não quer virar lixão atômico. Ecodebate. 2012b. Disponível em https://www.ecodebate.com.br/2012/05/29/uranio-da-bahia-caetite-nao-quer-virar-lixao-atomico/ acesso em: nov. 2015.

. Laboratório francês aponta contaminação ambiental em mina de urânio na Bahia. Ecodebate. 2014. Disponívem em: https://www.ecodebate.com.br/2014/05/15/denuncia-especialista-frances-critica-monitoramento-da-inb-em-caetite-ba/ Acesso em: nov. 2015.

. INB admite que urânio contamina água na Bahia. Ecodebate. 2015. Disponível em: https://www.ecodebate.com.br/2015/08/14/inb-admite-que-uranio-contamina-agua-na-bahia/ acesso em: nov. 2015.

ZONABEND, F. The Nuclear Peninsula. Cambridge: Cambridge University Press, 2007.

ZHOURI, Andréa (Org.) Mineração, violências e resistências: um campo aberto à produção de conhecimento no Brasil. Marabá, PA: Editorial iGuana, 2018. ABA. E-PUB. 
Israel de Jesus Rocha

\israelrocha@ufam.edu.br

ORCiD: https:// orcid.org/0000-0002-0890-8449
Submitted on: $14 / 06 / 2020$

Accepted on: 12/07/2021

2021;24e:00932

How to cite: ROCHA, I.J. Technoscientific reports, nuclearity and uranium production in Caetité/BA as a public issuel. Ambiente \& Sociedade. São Paulo, v. 24, p. 1-19, 2021. 


\title{
Relatórios tecnocientíficos, nuclearidades e a exploração de urânio em Caetité/BA como uma questão pública
}

\author{
Israel de Jesus Rocha
}

São Paulo. Vol. 24, 2021

Tema em destaque:

Insurgências Decolonais e Horizontes Emancipatórios: Contribuições da Ecologia Política
Resumo: A extração de urânio no Brasil tem suscitado questionamentos de diversos atores da sociedade civil, movimentos sociais e poderes públicos. Este artigo tem como objetivo descrever a produção de urânio como uma questão de interesse público a partir dos relatórios tecnocientíficos produzidos por instituições e grupos de pesquisa interessados em apresentar um diagnóstico sobre a situação da mina na região de Caetité, Estado da Bahia. Após descrição dos relatórios, percebemos a emergência de uma necessidade de monitoramento e mais transparência na forma de condução da exploração do urânio na região, sobretudo ligados à saúde de moradores e trabalhadores e a contaminação do ambiente e das águas. A atuação dos cientistas amplia a articulação das estratégias desenvolvidas pelos movimentos sociais locais e não locais concernidos com os problemas do nuclear no sentido de tornar as consequências da cadeia de exploração e produção do urânio e da energia nuclear um problema público.

Palavras-chave: Urânio; Nuclear; Relatórios científicos; Nuclearidade.

Como citar: ROCHA, I.J. Relatórios tecnocientíficos, nuclearidades e a exploração de urânio em Caetité/BA como uma questão pública. Ambiente \& Sociedade. São Paulo, v. 24, p. 1-19, 2021.

DOI: http://dx.doi.org/10.1590/1809-4422asoc20200093r2vu2021L4TD 


\title{
Informes tecnocientíficos, nuclearidad e la producción de uranio en Caetité/Ba como um problema publico
}

\author{
Israel de Jesus Rocha
}

São Paulo. Vol. 24, 2021

Tema en Destaque: Insurgencias Decoloniales y Horizontes Emancipatórios: Contribuiciones de la Ecología Política
Resumen: La extracción de uranio en Brasil ha suscitado dudas por parte de diversos actores de la sociedad civil, los movimientos sociales y las autoridades. Este artículo tiene como objetivo describir la producción de uranio como un problema público basados en informes tecnocientíficos producidos por instituciones y grupos de investigación interesados en presentar un diagnóstico sobre la situación de la mina en la región de Caetité. Después de describir los informes, surgió la necesidad de un monitoreo y una mayor transparencia en la forma de llevar a cabo la exploración de uranio en la región, especialmente relacionada con la salud de los residentes y trabajadores y la contaminación del medio ambiente y el agua. El papel de los científicos amplía la articulación de las estrategias desarrolladas por los movimientos sociales locales y no locales que se ocupan de los problemas nucleares para hacer que las consecuencias de la exploración y la cadena de producción de energía nuclear sean un problema público.

Palabras-clave: Uranio. Nuclear. Informes tecnocientíficos. Nuclearidad

Como citar: ROCHA, I. J. Informes tecnocientíficos, nuclearidad e la producción de uranio en Caetité/Ba como um problema publico. Ambiente $\mathbb{\&}$ Sociedade. São Paulo, v. 24, p. 1-19, 2021.

DOI: http://dx.doi.org/10.1590/1809-4422asoc20200093r2vu2021L4TD 